\title{
PROTEKSI MINAT DAN MOTIVASI BELAJAR AUD SELAMA MASA PANDEMI COVID 19 DI RA HIDAYATULLAH MEDAN MARELAN
}

\author{
Sakinah Siregar ${ }^{1}$, Rahmi Intan Sari ${ }^{2}$, Dewi Handayani ${ }^{3}$, Dewi Sartika ${ }^{4}$
}

\footnotetext{
${ }^{1}$ Institut Agama Islam Negeri Padangsidimpuan, ${ }^{2,3,4}$ Sekolah Tinggi Agama Islam Sumatera Medan JL.T Rizal Nurdin No.Km 4, Padang Sidempuan, Sumatera Utara e-mail: sakinahsiregar0501@gmail.com, rahmiintanpanyalai@gmail.com, dewihandayani12m@gmail.com, dewisartikatiki@gmail.com
}

\begin{abstract}
Abstrak: Penelitian ini bertujuan untuk menganalisis 1) Penyebab penurunan minat dan motivasi anak usia dini dalam mengikuti pembelajaran, (2) berbagai bentuk perilaku yang menurunkan minat dan motivasi anak usia dini, (3) Solusi penanganan penurunan minat dan motivasi anak usia dini. Metode penelitian yang digunakan adalah metode kualitatif, dengan teknik pengumpulan data yang digunakan adalah observasi, wawancara, dan dokumentasi yang kesemuanya dilakukan secara online. Hasil penelitian ini adalah Ragam Bentuk Perilaku Penurunan Minat dan Motivasi anak usia dini RA Hidayatullah Medan Marelan, yaitu: (1) Kurang antusias mengikuti pembelajaran, (2) Bosan belajar, (3) Tidak taat atau tidak mengikuti perintah guru, (4) Tidak mengikuti atau tidak mengikuti pelajaran. Sedangkan solusi penanganan penurunan minat dan motivasi anak usia dini, yaitu (1) dialog intens dengan orang tua dan siswa terkait, (2) mengemas pembelajaran dengan kegiatan bermain, (3) kelas minat khusus seminggu sekali, (3) kunjungan guru rumah siswa, (4) Multi-Dialog.
\end{abstract}

Kata Kunci: Proteksi, Minat, Motivasi, Pembelajaran.

\begin{abstract}
This study aims to analyze 1) The causes of decreased interest and motivation for early childhood in participating in learning, (2) various forms of behavior that reduce the interest and motivation of early childhood, (3) Solutions for handling decreased interest and motivation of early childhood. The research method used is a qualitative method, with data collection techniques used are observation, interviews, and documentation, all of which are done online. The results of this study are the Variety of Behavioral Forms of Decreasing Interest and Motivation of early childhood RA Hidayatullah Medan Marelan, namely: (1) Not enthusiastic about learning, (2) Tired of learning, (3) Disobedient or not following teacher orders, (4) Not follow or not follow the lesson. Meanwhile, solutions to reduce early childhood interest and motivation are (1) intense dialogue with parents and related students, (2) packaging learning with play activities, (3) special interest classes once a week, (3) visiting student home teachers, (4) Multi-Dialogue.
\end{abstract}

Keywords: Prtotection, Interest, Motivation, Learning.

\section{PENDAHULUAN}

Kemunculan pandemi Covid-19 memang memberikan dampak yang signifikan terhadap dunia pendidikan, pembelajaran yang dulu dilakukan secara tatap muka di dalam kelas bersama dengan guru dan teman, kini berubah menjadi pembelajaran jarak jauh dilakukan di rumah masing-masing, tidak bersama guru dan teman melainkan dilakukan dengan 
pendampingan orang tua/wali masingmasing. (Makarim, 2020). Sistem pembelajaran ini suka tidak suka memang harus diterima oleh semua orang sebab memang sudah menjadi peraturan pemerintah dalam skala nasional yang harus di taati oleh semua warga. (Fadlilah, 2020).

Jika mau ditelisik lebih jauh lagi, kondisi pandemi ini bukan hanya merubah tatanan sistem pembelajaran saja, melainkan juga merubah tatanan kehidupan stakeholder pendidikan, terkhusus para siswa dalam hal ini. Banyak perubahan sikap dan karakter yang dialami siswa selama menjalankan sistem pembelajaran jarak jauh.(R. R. Lubis \& Nasution, 2017). Salah satu sikap yang berubah tersebut yakni menurunya minat dan motivasi siswa untuk mengikuti pembelajaran. Bahkan bukan hanya dialami oleh satu atau dua anak bahkan hampir seluruhnya anak mengalami demikian. (M. Lubis, Yusri, \& Gusman, 2020).

Terkait dengan penurunan minat dan motivasi belajar siswa memang orang tua dihadapkan pada dua dilemma, yakni di satu sisi orang tua menyadari dan mengeluh dengan penurunan minat dan motivasi belajar siswa, di sisi lain orang tua juga menyadari bahwa tidak ada yang patut untuk dipersalahkan dengan kondisi penurunan tersebut, sebab mereka juga menyadari bahwa hal itu dikarenakan situasi dan kondisi pandemi yang sampai saat ini juga belum berakhir. Tak sedikit banyak orang tua yang akhirnya malah menggangap 'wajar' kondisi penurunan minat dan motivasi belajar anak. (Dewi, 2020).

Ketika pembelajaran di kelas sangat memungkinkan penurunan minat dan motivasi belajar siswa itu di atasi oleh guru, di tengah pandemi ini guru dan siswa di pisahkan oleh jarak sehingga tidak dapat sepenuhnya bagi guru untuk dapat mengatasi problem tersebut. Hal ini diasumsuikan akan sangat sulit untuk mengidentifikasi permasalahan penurunannya jika tidak bertatap muka. (Widyanuratikah, 2020). Sementara orang terdekat dalam kegiatan pembelajarn jarak jauh adalah orang tua siswa itu sendiri. Maka mau tidak mau, dalam konsisi ini oran tua akan memiliki peran ganda, yakni selain sebagai orang tua (pengasuh) kini mendapatkan tambahan tugas menjadi pengajar atau pendidik bagi anaknya sendiri. (Syah, 2020)

Kondisi penanganan turunnya minat dan motivasi pada tingkat usia dewasa memang bukanlah hal yang sulit untuk dilakukan sebab pada usia tersebut siwa sudah dapat secara mandiri mengelola minat dan motivasi belajarnya, kalaupun memerlukan bimbingan hanya bimbingan kecil saja, namun lain halnya pada anak usia dini, pada usia dini anak-anak yang mengalami problem penurunan minat dan motivasi belajar siswa sangat memerlukan pendampingan dari orang dewasa untuk mengatasinya. (Iftitah \& Anawaty, 2020). Dalam kondisi pembelajaran jarak jauh seperti ini maka sosok utama yang mengatasinya ialah orang tua, akan tetapi tidaklah dapat dilepaskan begitu saja, orang tua tetap membutuhkan dampingan, saran, 
dan masukan dari orang guru, walaupun caranya juga dilakukan dengan jarak jauh. (Khadijah, 2020) \& (Purwanto, 2020).

Pembelajaran yang dibatasi oleh ruang dan waktu membuat anak tidak dapat mengakses secara penuh fasilitas pembelajaran yang selama ini mereka dapatkan, anak-anak pun tidak diberikan ruang yang penuh untuk mengembangkan minat dan motivasinya hal-hal tertentu yang harus di patuhi secara bersama sebagai wujud dalam peningkatan kewaspadaaan terhadap keberadaan virus Covid-19. (Rohayani, 2020). Akibat dari pembatasan ini salah satunya berdampak pada turunnya minat dan motivasi belajar siswa untuk mengikuti pembelajaran. Di tambah lagi kondisi pembelajaran yang minim dengan fasilitas bermain, sebab selama ini memang tak dapat di pungkiri bahwa pembelajaran AUD cenderung dengan kegiatan bermain. (Arifa, 2020)

Kondisi yang telah disebutkan di atas sebenarnya menggambarkan kondisi yang terjadi di RA Hidayatullah Medan Marelan, saat ini berdasarkan wawancara awal peneliti dengan salah seorang tenaga pengajar di lembaga tersebut yakni ibu Syarifah Lubis setidaknya $60 \%$ siswa mengalami penurunan minat dan motivasi belajar. Hal ini ditunjukkan dengan beberapa perilaku yang berbeda-beda. Kondisi ini memang membuat para guru menjadi khawatir, sebab pada level tertinggi penurunan minat dan motivasi ini sampai pada ketidakikusertaan mereka mengikuti pembelajaran online.

Perlu diketahui bahwa penelitian sejenis ini memang telah diteliti oleh beberapa orang, salah satunya penelitian yang dilakukan oleh Azizah Nurul Fadlilah dengan judul Strategi Menghidupkan Motivasi Belajar Anak Usia Dini Selama Pandemi COVID-19 melalui Publikasi, adapun hasil penelitiannya menunjukkan bentuk strategi guru untuk menghidupkan motivasi belajar siswa dalam kebijakan SFH di tengah wabah COVID-19 adalah dengan publikasi hasil kerja tugas siswa yang terbukti dapat menghidupkan motivasi belajar siswa. Hambatan yang ditemui guru yaitu berkenaan dengan aspek orang tua peserta didik, sarana pembelajaran, dan kreativitas guru. Manfaatnya berupa tumbuhnya motivasi belajar siswa, melatih kedisiplinan siswa, serta membantu meningkatkan kedekatan antara orangtua dan anak.(Fadlilah, 2020). Bedanya dengan penelitian ini ialah penelitian ini lebih berfokus pada sisi proteksi yang dilakukan oleh orang tua dan guru. Sebab pada kasus di lembaga RA Hidayatullah Medan Marelan rerata siswa mengalami gangguan penurunan minat dan motivasi, sehingga sangat membutuhkan informasi tentang bagaimana mengatasinya, sebab tidak jarang ditemui beberapa siswa yang tidak lagi mengingkan untuk mengikuti pembelajaran.

Oleh karena itulah berdasarkan halhal di atas penulis tertaraik untuk melakukan penelitian dengan judul Proteksi Minat Dan Motivasi Belajar AUD Selama Masa Pandemi Covid 19 di RA Hidayatullah Medan Marelan. Adapun fokus penelitannya di arahkan pada tiga hal yakni: (1) Penyebab penurunan Minat dan Motivasi AUD dalam mengikuti 
pembelajaran, (2) ragam bentuk perilaku penurunan minat dan motivasi AUD, (3) Solusi penanganan penurunan minat dan motivasi AUD.

Untuk lebih mengokohkan pembahasan ini di bawah ini akan dipaparkan beberapa depkripsi teoritis terkait dengan topik penelitian ini, tujuanya sebagai landasan dalam membahas temuan penelitian. Pertama di awali dengan medefinisikan minat dan motivasi Belajar. Pada dasarnya keduanya merupakan pembahasan pada disiplin ilmu psikologi, namun saat ini keduanya lazim juga di bahas pada dunia pendidikan. Secara Bahasa minat di artikan sebagai Minat merupakan rasa suka atau ketertarikan seseorang terhadap suatu hal tertentu. Sementara itu, motivasi adalah dorongan dari dalam diri manusia untuk melakukan suatu kegiatan. (Aritonang, 2008).

Dalam penelitian ini minat disandingkan dengan ketertarikan siswa untuk mengikuti ragam atau jenis pembelajaran yang diberikan oleh guru, sebab dalam satu minggu pembelajaran hanya dilakukan tiga kali pertemuan dengan ragam pembelajaran yang berbeda, walaupun diajarkan secara tematik. Sedangkan motivasi dalam penelitian ini disandingkan dengan dorongan untuk melakukan seluruh kegiatan pembelajaran dan melaksanakan semua tugas-tugas yang diberikan oleh guru.

Sebagaimana di ketahui bahwa baik minat dan motivasi keduanya dipengaruhi oleh faktor yang berasal dari dalam (internal) dan dari luar (eksternal). Dari dalam berarti berkaitan dengan kemampuan diri, kesehatan, mental, dan pemahamannya terhadap sesuatu hal, sedangkan yang dari eksternal berarti berkaitan dengan lingkungan, interaksi sosial, kondisi dan situasi di sekitar. (Yus, 2011). Secara umum memang semua orang sepakat bahwa gangguan minat dan bakat siswa rerata di pengaruhi oleh faktor eksternal yakni situasi dan kondisi merebaknya pandemic Covid-19. Dengan adanya aturan batasan pertemuan, batasan penggunaan waktu, batasan jarak berkomunikasi, batasan materi pelajaran, sehingga membuat siswa mengalami penurunan minat dan motivasi dalam mengikuti pembelajaran. (Hasibuan \& Panjaitan, 2020) \&

\section{METODE PENELITIAN}

Penelitian ini menggunakan metode penelitian kualitatif, dengan pendekatan yang digunakan ialah studi kasus. Metode penelitian kualitatif maksudnya dalam hal ini peneliti mencoba untuk mengungkap dan mendeskripsikan (lewat interpretasi penulis) fenomena dan fakta dilapangan terkait dengan topik penelitian yang sedang dikaji. Sedangkan pemilihan Studi kasus lebih mengarah pada kareteristik permasalahan penelitian ini, yang dahulunya tidak terjadi sementara ketika pandemic muncul problematika tersebut pun muncul. Studi kasus menurut Creswell artinya ialah kegiatan menganalisis terhadap satu atau beberapa kasus yang dianggap signifikan dan relevan untuk di angkat ke permukaan dengan pertimbangan manfaat yang akan di dapat. 
Penelitian ini dilaksanakan di RA Hidayatullah Medan Marelan yang beralamat di jalan Marelan IX Link VII Gg.Parlik Kel Tanah Enam Ratus Kecamatan Medan Marelan. Namun dikarenakan situasi dan kondisi pencegahan penyebaran wabah Covid-19 maka penelitian lebih cenderung dilakukan secara online. Pemilihan lokasi ini karena memang kasus yang telah di paparkan pada bagian pendahuluan terjadi di lembaga ini, dan levelnya berada pada yang sangat memprihatinkan yakni sekitar $60 \%$ siswa mengalami gangguan penurunan minat dan motivasi AUD.

Sumber data pada penelitian ini ada tiga yakni Guru, orang tua, dan siswa. Adapun data utama di peroleh dari Orang tua, data yang akan digali dari orang tua yakni mengenai kondisi penurunan yang dialami oleh anak, dan bagaimana bentuk kerjasama orang tua dan guru dalam memproteksi minat dan motivasi belajar AUD. Pada diri guru akan dicari dan diperoleh data terkait dengan bagaimana solusi dan bentuk kerjasama orang tua dan guru dalam memproteksi minat dan motivasi belajar AUD. Sedangkan pada diri siswa akan di cari dan diperoleh data berkaitan dengan bentuk-bentuk prilaku yang muncul yang menjadi indikasi menurunnya minat dan motivasi belajar AUD.

Dalam pengumupulan data dilakukan beberapa teknik pengumpulan data, yakni:

a. Observasi, yakni pengamatan secara lansung tentang keikutsertaan siswa dan orang tua dalam mengikuti pembelajaran berbasis daring. Pengamatan ini tidak dilakukan secara tatap muka, akan tetapi dilakukan berdasarkan kegiatan pembelajaran daring langsung atau berdasarkan hasil terkaman kegiatan pembelajaran yang telah di kemas dalam bentuk rekaman .

b. Wawancara, kegiatan dialog kepada responden dalam hal ini adalah guru, orang tua dan siswa. kepada guru diajukan 10 pertanyaan terkait dengan bentuk-bentuk prilaku yang di tampilkan anak sebagai karakteristik gangguan penurunan minat dan motivasi belajar mereka. Kepada orang tua diajukan 10 pertanyaan terkait cara mereka dalam menangani gangguan penurunan minat dan motivasi. Kepada siswa sendiri akan diajukan sekitar 5 pertanyaan terkait alasan mereka berprilaku yang menampilkan penurunan minat dan motivasi mengikuti pelajaran.

c. Dokumentasi, kegiatan ini dilakukan dengan cara mengamati dokumendokumen yang berkaitan dengan kegiatan pembelajaran seperti dokumen Rencana pembelajaran harian, rekaman kegiatan, dan tugas siswa selama pembelajaran

Prosedur Penelitian terdiri dari kegiatan pengumpulan data, reduksi data, penyajian data, penarikan kesimpulan. Secara alur dapat digambarkan seperti di bawah ini: 


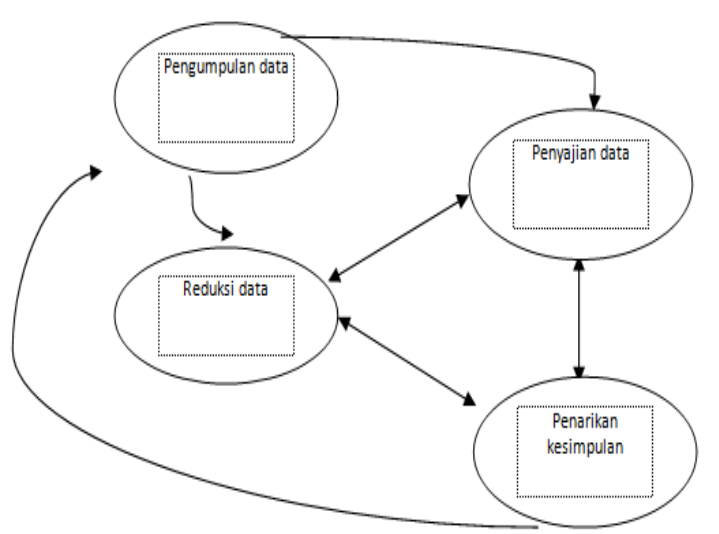

Gambar 1. Alur prosedur penelitan

Teknik analisis data dalam penelitian ini menggunakan teknik analisis deskkriptif-induktif. Dalam arti temuantemuan penelitian yang bersifat khusus lantas di analisis dengan cara mendeskripsikannya menggunakan interpretasi penulis. Walaupun penelitian ini menggunakan interpretasi si penulis, namun interpretasi di usahakan tetap berpijakan pada temuan penelitian yang ada.

\section{HASIL DAN PEMBAHASAN}

Pembahasan penelitian akan disesuai dengan fokus penelitian sebagaiamana yang tertera pada bagian pendahuluan. Hal tersebut untuk memudahkan para pembaca dalam memahami pembahasan hasil penelitian ini.

1. Penyebab penurunan Minat dan

Motivasi AUD dalam mengikuti pembelajaran

Berdasarkan hasil wawancara dengan guru di RA Hidayatullah Medan Marelan diketahui bahwa ada beberapa faktor yang menyebabkan AUD di RA tersebut mengalami problematika penurunan minat dan motivasi belajar selama masa pandemic Covid-19. Yakni sebagai berikut:

a. Keterbatasan jarak antara siswa dan guru

Jarak yang memisahkan antara guru dan siswa selama pembelajaran daring, memang membuat siswa merasa jenuh untuk mengikuti pembelajaran sehingga lambat laun anak mengalami penurunan motivasi belajar. Selama ini sebelum terjadinya pandemic Covid-19 anak-anak dengan senang hati belajar dengan guru bersama-sama dengan teman, akan tetapi kebijakan pemerintah yan memberikan batasan jarak membuat anak semaki hari semakin jenuh untuk melaksanakan pembelajaran dan mengerjakan tugas-tugas yang diberikann guru.

Sebenarnya walaupun dibatasi jarak, atau dengan kata lain belajar dari rumah, anak-anak tetap dapat berinteraksi dengan gurunya melalui jaringan seluler, hanya saja ketidakmammpuan untuk saling bertemu membuat anak semakin hari semakin mengalami penurunan. Sebenarnya alasannya ketik peneliti mewawancarai anak di RA tersebut ialah pada ketidakpuasan untuk berbicara karena dibatasi oleh jarak dan waktu, di tambah lagi anak tidak dapat menjangkau seluruh teman-teman bermainnya.

b. Keterbatasan dalam pengawasan dan perhatian

Selama pembelajaran daring tentu para guru di RA ini mengaku sulitnya untuk memberikan pengawasan dan perhatian lebih kepada tiap anak. Hal ini 
wajar saja terjadi karena kondisi kebijakan yang tak memungkinkan untuk melakukan demikian. Ditambah lagi pembelajaran tentu dilakukan dengan cara pemberian tugas ataupun penjelasan singkat lewat video yang dikirimkan di group Whatsapp. Akhirnya anak-anak melaksanakan pekerjaan rumah tersebut dengan di bantu orang tua. Pemberian tugas pun dilaksanakan secara general, artinya dalam hal ini tidak ada pertimbangan khusus terkait dengan minat masig-masing anak.

Selama ini menurut pengakuan salah seorang guru yang bernama Sarifah lubis menjelaskan bahwa RA ini mempertimbangkan minat dan bakat mahasiswa dalam mendesain pembelajaranya. Prosedurnya, guru bekerjasama untuk mengelompokkan minat dan bakat siswa lantas, minat yang terkelompok itu di klasifikasikan menjadi beberapa kelompok lagi, dan guru mendesain tema pembelajaran berdasarkan karekteristik minat dan bakat anak. Namun di tengah kondisi yang sulit ini guru-guru di RA ini mengaku kesulitan untuk mengidentifikasinya satu persatu.

c. Keterbatasan dalam pilian jenis pembelajaran dan permainan

Dalam satu minggu pembelajaran lazimnya guru memberikan pembelajaran dengan penekanan kompetensi yang berbeda-beda satu sama lain. Tidak hanya itu dalam satu minggu waktu belajarpun guru memberikan penekanan permainan yang berbeda-beda (lazimnya pembelajaran di kemas dalam bentuk kegiatan bermain). Namun karena semua itu tidak bisa terlaksana selama masa pandemic Covid-19 maka menyebabkan penurunan minat dan motivasi mereka untuk mengikuti pembelajaran. Selama masa Pandemi siswa di RA Hidayatullah Medan Marelan hanya melaksanakan pembelajaran tiga kali dalam satu minggu, dengan durasi waktu pembelajaran hanya satu jam. Tentu dengan kondisi waktu yang sangat singkat tersebut tidak banyak yang dapat dilakukan guru, akhirnya pembelajaran 'satu untuk semua', setiap siswa di wajibkan mengerjaan pekerjaan rumah yang sama. Analisis penulis dalam hal ini tentu akan mempengaruhi minat dan motivasi, sebab anak akan terkekang hanya pada satu pilihan saja, sementara tidak semua pilihan yang ada sesuai dengan minat siswa. Ada anak yang sangat minat pada pembelajaran bidang seni menari dan bernyanyi, sementara pembelajaran daring tidak semua kegiatan tersebut dapat tersalurkan dengan baik dalam waktu belajar yang singkat.

\section{d. Self-control yang belum matang}

Seperti yang telah dijelaskan di atas bahwa pada masa usia dewasa mungkin sangat mudah bagi mereka untuk mengontrol dirinya sendiri secara mandiri. Akan tetapi tidak pada anak usia dini yang memang membutuhkan orang dewasa di sekitarnya. Anak usia dini tentu membutuhkan orang dewasa sebagai sosok yang membimbing mereka dan mengarahkan mereka untuk mampu megontrol berbagai macam problem dari luar, seperti tontonan televisi, pengaruh teman, reward atau punishment, dan lainnya. Problem itu tentu menjadi 
pengaruh bagi motivasi anak untuk mengikuti pelajaran. Oleh karena mereka tak mampu untuk mengontrol dirinya sendiri di tambah lagi menurut penuturan guru di RA ini minimnya perhatian dari orang tua, maka tentulah sangat mempengaruhi kondisi minat dan motivasi anak. (Anisah, 2017).

2. Ragam Bentuk Perilaku Penurunan minat dan Motivasi AUD,

Penurunan minat dan motivasi AUD dalam mengikuti pembelajaran selama masa pandemi Covid 19 di tandai dengan beberapa perilaku yang menyimpang yang tak biasanya terjadi pada usia demikian. Beberapa perilaku yang akan disebutkan di bawah ini merupakan hasil pengamatan peneliti pada kegiatan pembelajaran daring peserta didik. Dikemukakannya perilaku ini untuk menunjukkan karekteristik atau ciriciri anak-anak usia dini yang mengalami gangguan penurunan minat dan motivasi belajar. Adapun beberapa perilaku yang dimaksud sebagai berikut:

a. Tidak antusias mengikuti pembelajaran

Beberapa anak setelah diamati menunjukkan sikap tidak antusias terhadap penyampaian materi oleh guru. Tidak antusias ini ditampilkan dengan sikap acuh tak acuh dalam mengikuti pembelajaran. Ada beberapa anak yang cuek saat gurunya menyampaikan materi pelajaran, ada anak yang tidak ikut serta secara total kegiatan (tidak ikut sampai selesai). Ketika peneliti mewawancarai orang tua anak terkait dengan sikap-sikap tidak antusias tersebut, rerata guru mengatakan bahwa anak-anak tidak meminati materi yang diajarkan, penjelasan yang sulit untuk dicerna melalui daring juga menyebabkan kehilangan motivasi pada anak untuk belajar.

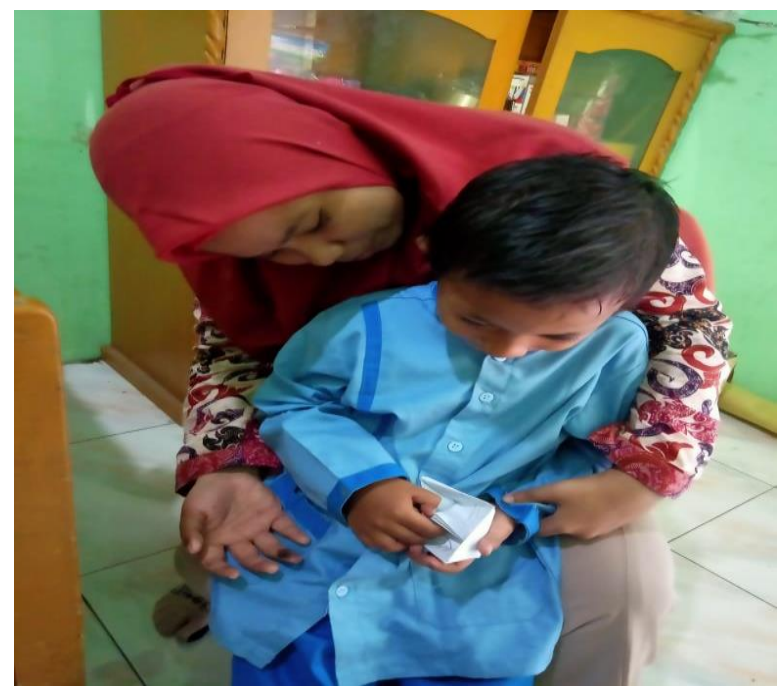

Gambar 2. sikap tidak antusias untuk belajar

b. Merasa jenuh mengikuti pembelajaran

Rasa jenuh memang tidak selamanya menunjukkan penurunan minat dan motivasi belajar anak. Bisa juga rasa jenuh disebabkan karena kurang sehat yang dialami oleh anak. Namun dalam hal ini pengamatan penulis terhadap sikap jenuh yang dialami oleh anak-anak karena beberapa anak memiliki persepsi bahwa materi konten pembelajaran tidak sesuai dengan minat dan motivasi anak. Hal ini sebagaimana diungkapkan oleh orang tua siswa yang mengaku bahwa keinginan anak dalam pembelajaran teesuai dengan minat dan motivasi anak. Hal ini sebagaimana diungkapkan oleh orang tua siswa yang mengaku bahwa keinginan anak dalam pembelajaran terdapat kegiatan fisik yang mendukung perkembangan motorik anak, hanya saja terkadang materi tidak tentu 
menjangkau minat dan motivasi seluruh siswa.

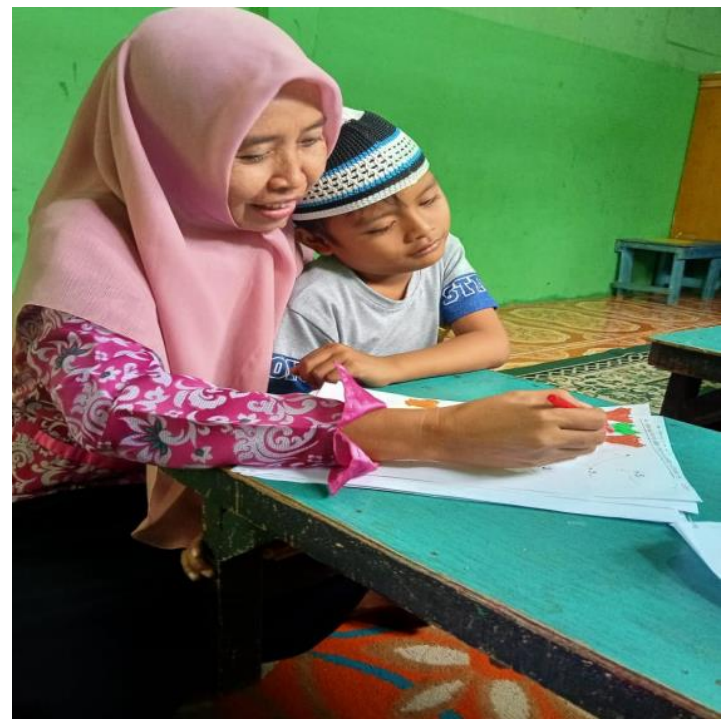

Gambar 3. Sikap jenuh anak

c. Membangkang atau tidak mengikuti perintah guru

Menurunya motivasi siswa di RA Hidayatullah Medan marelan juga di tandai dengan adanya sikap membangkang yang ditunjukkan oleh beberapa anak. Ketika guru memberikan tugas, beberapa anak tidak suka atau menolak tugas ini, seperti dengan ungkapan 'tidak mau', 'capek', 'males' dan sebagainya. Berdasarkan analisis peneliti terhadap perilaku ini sebenarnya perilaku ini menunjukkan tentang menurunya motivasi anak mengikuti pembelajaran yang menurut mereka semakin hari semakin membosankan, karena tak dapat bertatap muka, dan bermain bersama, dalam hal ini tentu muaranya ialah tidak tersedianya ruang untuk menyalurkan minat mereka.

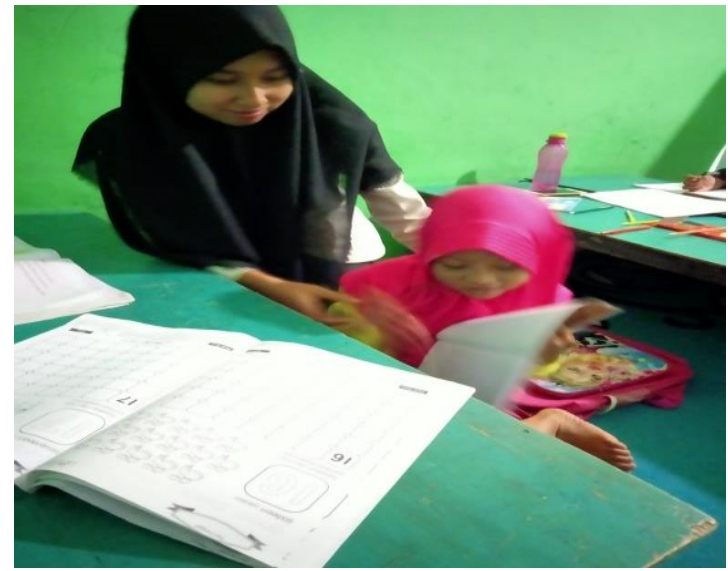

Gambar 4. Anak Menolak untuk belajar

d. Abstain atau tidak mengikuti pembelajaran

Menurut peneliti ketidakhadiran anak dalam mengikuti pembelajaran sesuai dengan jadwal dapat dikatakan sebagai klimaks atau puncak hilangnya motivasi dan minat siswa untuk mengikuti pembelajaran. Menurut penjelasan guru memang jumlah yang abstain tidaklah terlalu banyak hanya saja jumlah ini setidaknya mememberikan idikasi kepada pengelola RA Hidayatullah Medan Marelan bahwa sistem pembelajaran daring seperti itu tidak diminati oleh sebagian siswa, tentu efeknya siswa akan kesulitan dalam pengembangan kemampuannya sebab tidak mengikuti pembelajaran sebagaimana layaknya teman yang lain.

3. Solusi penanganan penurunan minat dan motivasi AUD

Sebagaimana yang telah penulis sebutkan sebelumnya bahwa terkadang orang tua tidak menyadari tentang penurunan minat dan motivasi AUD. Hal itu dikarenakan menganggap bahwa semua itu dikarenakan kondisi dan situasi yang 
ada. Namun para orang tua tidak menyadari bahwa penurunan itu dapat berakibat meluas yang bukan hanya pada penurunan minat dan motivasi akan tetapi bisa berakibat pada gangguan lain seperti gangguan keterlambatan berbicara pada AUD, gangguan motorik halus dan kasar, dan sebagainya. Untuk itulah perlu diberikan penanganan terhadap penurunan minat dan motivasi AUD.

Proses penetapan bahwa siswa mengalami penurunan minat dan motivasi AUD tidaklah berjalan begitu saja melainkan terlebih dahulu dilakukan diagnosa atau identifikasi terhadap perilaku-perilaku yang tak lazim di tampilkan oleh siswa. Berdasarkan pengamatan penulis, identifikasi ini dilakukan oleh guru dengan cara memperhatikan langsung hasil penugasan video yang dikirimkan oleh siswa kepada gurunya, jika memang ternyata terdiagnosa bahwa anak mengalami gangguan penurunan minat dan motivasi, maka guru memberikan teguran dan pemberitahuan kepada orang tua lewat surat tertulis atau lewat pembicaraan telefon, atau penulis amati juga dilakukan dengan pemberitahuan melalui pesan whatsapp.(Ayuni, Marini, Fauziddin, \& Pahrul, 2020).

Penanganan penurunan minat dan motivasi AUD sebagaimana yang akan disebutkan berikut ini hanya bersifat treatment yang dilakukan oleh orang tua dan guru saja. Hal ini dikarenakan permasalahan penurunan minatnya tidak harus sampai di tangani oleh psikolog.
Adapun beberapa solusi penanganan sebagaimana yang berhasil penulis amati, sebagai berikut:

a. Dialog intens dengan orang tua dan siswa bersangkutan

Sebagaimana yang penulis amati bahwa untuk menangani penurunan minat dan motivasi AUD di RA Hidayatullah Medan Marelan guru melakukan dialog intens kepada siswa. Setelah teridentifikasi bahwa terdapat anak dengan gangguan minat dan motivasi belajar, ma secepatnya guru melakukan dialog intens dengan siswa bersangkutan lewat sambungan video call atau bahkan terkadang dengan pertemuan langsung (dikarenakan rumah siswa dan guru tidak terlalu jauh). Dialog intens yang dimaksud ialah dialog yang mengkhususkan untuk penanganan penurunan minat dan motivasi belajar. Sebagaimana yang telah penulis amati terdapat seorang guru bernama ibu Siti yang melakukan kunjungan ke rumah siswa untuk bersilaturrahim dan melakukan dialog intens.

Dari yang penulis amati, pada kegiatan dialog ini dang guru memberikan informasi terkait hasil identifikasinya dan mengajak orang tua untuk mau bekerja sama dalam penurunan minat dan motivasi belajar tersebut. Di sela-sela kegiatan guru dan orang tua, serta siswa menyempatkan diri untuk saling bercanda dan tertawa, sambil membahas secara intens penurunan minat dan bakat yang terjadi pada AUD tersebut. Sebagai bentuk follow up dari kegiatan ini guru melakukan teguran dan pemberian masukan dan saran kepada 
orang tua. Seperti yang penulis amati pemberian masukan dan saran ini akan terus di pantau dengan cara memperhatikan perubahan dari permasalahan yang di alami oleh anak tersebut.

Teori perkembangan menunjukkan bahwa anak berkembang dengan dampingan orang dewasa di sekitarnya, oleh karena itu tidaklah salah jika penanganan penurunan ini juga memerlukan bantuan orang tua. Secara teoritis orang tua atau orang dewasa di sekitarnya memang memberikan dampak yang besar terhadap perubahan sikap anak. Di tambah lagi orang tua merupakan sosok yang paling dekat dengan anak, dan dengan adanya pandemi Covid ini orang tua dan anak memiliki waktu bertemu yang lebih lama dibanding dengan sebelum datangnya pandemi Covid-19.

b. Mengemas pembelajaran dengan kegiatan bermain

Mengemas pembelajaran dengan kgiatan bermain dilakukan oleh guru sebagai bentuk penanganan penurunan motivasi belajar siswa, sebab selama ini pembelajaran sebagaimana yang peneliti amati hanya sekedar bentuk penugasan saja, sementara kegiatan bermain jarang dilakukan. Bentuk-bentuk penugasan sebagaimana yang penulis amati yakni melalui guru memberikan tugas (seperti: perhitungan, penulisan huruf, melakukan motorik) dengan cara merekam perintah tugas dan langkah-langkahnya lewat video yang lalu di kirimkan di grou whatsapp. Model penugasan ini berulang terjadi setiap hari pembelajaran, tentu pola ini membuat jenuh para siswa, sebab siswa merasa terbatasi dalam mengeksplorasi kemampuannya.

Guru menyadari bahwa dengan kegiatan yang ada selama ini perlu untuk di rubah. Perubahan yang dilakukan guru ialah dengan mengemas pembelajaran menjadi kegiatan bermain. Materi pelajaran tidak berubah, tetap sebagaimana rencana pembelajaran harian yang telah ditulis, hanya saja yang selama ini pembelajaran selalu di kemas dengan kegiatan berbasis kognitif seperti berhitung dan menulis, kini dikemas menjadi bermain. Dalam permainan yang didesain oleh guru tetap ada kegiatan berhitung dan menulis, namun berhitung dan menulis dilakukan sambil bermain. Seperti contohnya yang berhasil penulis lakukan ialah bermain ular tangga, dalam permainan ini sang guru menginginkan anak terampil dalam mengenal angka, sehingga secara tak langsung dengan kegiatan bermain 'ular tangga' dadu yang di aduk disertai dengan angka-angka akan memberikan kemampuan kepada siswa dalam mengingat dan menghitung langkah-demi langkah kotak-kotak yang ada pada kertas permainan ular tangga.(Khadijah \& Armanila, 2017).

Kegiatan bermain diharapkan dapat merangsang kembali motivasi mereka untuk belajar. Sifat permainan yang mengasyikkan, dan membuat riang siswa, diharapkan mampu untuk membangkitkan motivasi mereka yang sempat menurun karena jenuhnya dengan penugasan yang menumpuk setiap hari. Permainan termasuk 
penugasan, akan tetapi penugasan yang dikemas dengan cara kegiatan bermain. (Sari, Mutmainah, Yulianingsih, Tarihoran, \& Bahfen, 2020).

Hasil wawancara dengan guru dan orang tua, cara mengemas pembelajaran dengan kegiatan bermain memang termasuk berhasil dalam menangani penurunan motivasi belajar siswa, $75 \%$ Siswa merasa sangat senang jika pembelajaran dikemas dengan kegiatan bermain. Orang tuapun mengaku bahwa tidak mengalami kesulitan untuk merayu dan membujuk anaknya untuk belajar, bahkan dalam hal ini orang tua menjadi sangat terbantu.

c. Kelas minat khusus satu minggu sekali

Untuk menangani penurunan minat siswa, guru memberikan ruang dan waktu khusus kepada AUD di RA Hidayatullah dalam satu minggu satu kali. Hari itu di khususkan bagi siswa menyalurkan minatnya. Pada hari itu siswa di bebaskan untuk memakai pakaian sesuai dengan minat mereka. Hal ini sebagaimana yang peneliti amati beberapa siswa memang mengenakan seragam yang menujukkan minat seperti ada yang mengenakan pakaian seragam polisi, ada yang mengenakan pakaian seragam tentara, seragam nahkoda, seragam guru dan sebagainya. Pengkhususan hari ini memang disambut baik oleh orang tua, sebab selama pandemi anak-anak hanya belajar menggunakan pakaian rumah biasa.

Sebenarnya tidak hanya pakaian, akan tetapi pengkhususan ini juga diberikan dalam memilih tema ataupun kegiatan pembelajaran. Anak di bebaskan untuk memilih pembelajaran sebagaimana yang ia suka, tentu dalam hal tampak perbedaan satu sama lain antara satu siswa dengan siswa lainnya. Hasil pengamatan penulis terhadap kekhususan ini ini tampak beberapa kegiatan ada yang mewarnai, ada yan bernyanyi ada juga yang bercerita dan sebagainya. Intinya pada kegiatan ini anak di bebaskan untuk memilih apapun yang diminatinya.

d. Guru mengunjungi rumah siswa

Sejauh pengamatan peneliti untuk solusi ini memang tidaklah masif dilakukan oleh guru. Sebab jenis solusi ini dilakukan terhadap siswa yang memang kondisi penuruanan minat dan motivasinya sudah tak terkendalikan lagi, atau dengan kata lain hampir dikatakan tidak pernah lagi mengikuti pembelajaran.

Ketidakikutsertaan siswa selama mengikuti pembelajaran tentu menjadi tanda Tanya bagi guru, sehingga perlu untuk dikunjungi kerumah. Kegiatan berkunjung ini bukan semata untuk bertemu dengan sang anak semata, akan tetapi yang lebih terpenting untuk mengetahui problematika yang sebenarnya terjadi dengan mengkrosceknya kepada orang tua. Sebab dalam kondisi ini tidak semua problem itu diakibatkan karena permasalahan ekonomi. Sebagaimana hasil pengamatan peneliti terhadap kondisi ini, ditemui alasan beberapa orang tua yang mengaku bahwa pembelajaran daring tidak terlalu urgent bagi mereka, sebab sebagian orang tua menganggap anak sulit 
menangkap atau memahami pelajaran lewat jaringan internet tersebut.

Dengan demikian maka peeliti memberikan kesimpulan bahwa sebenarnya kegiatan mengunjungi ini merupakan bagian dari kepedulian guru terhadap kondisi siswa yang tidak mengikuti pembelajaran. Ketidakikutsertaannya dalam pembelajaran tentu mengakibatkan penurunan motivasinya untuk mengikuti pembelajaran. Walaupun memang sejauh pengamatan peneliti tidak semua siswa yang telah dikunjungi oleh guru lantas berhasil memberikan semangat dan masukan kepada mereka dan mau untk kembali mengikuti pembelajaran online.

\section{e. Multi-Dialog}

Selama ini pembelajraan selalu dilakukan guru dengan cara memberikan peugasan kepada siwa melalui rekaman tugas yang telah di buat guru lalu di kirim lewat whats app. Namun kegiatan itu tentu menutup akses kepada teman-teman lain untuk saling berkomunikasi dan bertatap muka.Oleh karena itu pembelajaran juga terkadang dilakukan guru dengan cara multi dialog, atau bertatap muka secara langsung secara keseluruhan lewat jaringan virtual. Aplikasi yang dipakai pada kegiatan ini adalah zoom, akan tetapi model kegiatan ini tidak dilakukan setiap hari, hanya dilakukan pada waktu-waktu tertentu saja, seperti yang penulis amati terkadang satu bulan sekali.

Kegiatan multi dialog ini mengajak siswa untuk bertemu dengan teman-teman lainnya sehingga menarik minat dan perhatian mereka untuk mengikuti pembelajaran secara bersama-sama, kebersamaan ini tentu selalu dilakukan selama sebelum masa pandemic Covid-19, akan tetapi tidak setelah kemunculan masa pandemik. Para guru memberikan penuturan bahwa pembelajaran yang dilakukan dengan cara individu cenderung membuat mereka merasa jenuh, dan cenderung mengalami permasalahan sosial. (Yulisetyaningrum, 2019). Oleh karena itu selain untuk mengatasi penurunan minat dan motivasi siswa, kegiatan ini juga dapat meningkatkan kecerdasan sosial siswa.

\section{SIMPULAN}

Penurunan minat dan motivasi belajar siswa AUD bukan hanya menjadi tanggung jawab pribadi anak masingmasing, akan tetapi menjadi tanggung jawab guru dan orang tua, sebab pada masa usia tersebut anak belum dapat secara mandiri mengontrol dan mengendalikan dirinya sendiri. Di RA Hidayatullah Medan Marelan Penyebab penurunan Minat dan Motivasi AUD dalam mengikuti pembelajaran ada empat yakni (1) Keterbatasan jarak antara siswa dan guru, (2) Keterbatasan dalam pengawasan dan perhatian (3) Keterbatasan dalam pilian jenis pembelajaran dan permainan, (4) Selfcontrol yang belum matang. Adapun Ragam Bentuk Perilaku Penurunan minat dan Motivasi AUD RA Hidayatullah Medan Marelan, yakni: (1) Tidak antusias mengikuti pembelajaran, (2) Merasa jenuh mengikuti pembelajaran, (3) Membangkang atau tidak mengikuti perintah guru, (4) 
Abstain atau tidak mengikuti pembelajaran.

Sedangkan Solusi penanganan penurunan minat dan motivasi AUD, yakni (1) Dialog intens dengan orang tua dan siswa bersangkutan, (2) Mengemas pembelajaran dengan kegiatan bermain, (3) Kelas minat khusus satu minggu sekali, (3) Guru mengunjungi rumah siswa, (4) MultiDialog.

\section{DAFTAR PUSTAKA}

Anisah, A. S. (2017). Pola asuh orang tua dan implikasinya terhadap pembentukan karakter anak. Jurnal Pendidikan UNIGA, 5(1), 70-84.

Arifa, F. N. (2020). Tantangan Pelaksanaan Kebijakan Belajar Dari Rumah Dalam Masa Darurat Covid-19. Info Singkat, Kajian Singkat Terhadap Isu Aktuan Dan Strategis, XII(No. 7/I/Puslit/April/2020), 13-18. Retrieved from http://puslit.dpr.go.id

Aritonang, K. T. (2008). Minat dan motivasi dalam meningkatkan hasil belajar siswa. Jurnal Pendidikan Penabur, 7(10), 11-21.

Ayuni, D., Marini, T., Fauziddin, M., \& Pahrul, Y. (2020). Kesiapan Guru TK Menghadapi Pembelajaran Daring Masa Pandemi Covid-19. Jurnal Obsesi: Jurnal Pendidikan Anak Usia Dini, 5(1), 414-421.

Dewi, W. A. F. (2020). Dampak Covid-19 Terhadap Implementasi Pembelajaran Daring Di Sekolah Dasar. Edukatif: Jurnal Ilmu Pendidikan, 2(1), 55-61. https://doi.org/https://doi.org/10.3100 4/edukatif.v2i1.89

Fadlilah, A. N. (2020). Strategi Menghidupkan Motivasi Belajar Anak Usia Dini Selama Pandemi COVID-19 melalui Publikasi. Jurnal Obsesi: Jurnal Pendidikan Anak Usia
Dini, 5(1), 373-384.

Hasibuan, H. R., \& Panjaitan, R. W. (2020). Pemikiran Ibnu Qoyyim tentang Proteksi Minat dan Motivasi Belajar dalam Kitab Ad-daa'wa Addawaa'. Fitrah: Journal of Islamic Education, 1(1), 55-71.

Iftitah, S. L., \& Anawaty, M. F. (2020). Peran Orang Tua Dalam Mendampingi Anak Di Rumah Selama Pandemi Covid-19. JCE (Journal of Childhood Education), 4(2), 71-81.

Khadijah, \& Armanila. (2017). Bermain dan Permainan Anak Usia dini. Medan: Perdana Publishing.

Khadijah, K. (2020). Pola Kerja Sama Guru Dan Orangtua Mengelola Bermain Aud Selama Masa Pandemi Covid19. Kumara Cendekia, 8(2), 154-170.

Lubis, M., Yusri, D., \& Gusman, M. (2020). Pembelajaran Pendidikan Agama Islam Berbasis E-Learning (Studi Inovasi Pendidik MTS. PAI Medan di Tengah Wabah Covid-19). Fitrah: Journal of Islamic Education, 1(1), 1-15.

Lubis, R. R., \& Nasution, M. H. (2017). Implementasi Pendidikan Karakter di Madrasah. JIP (Jurnal Ilmiah PGMI), 3(1), 15-32.

Makarim, N. anwar. Surat Edaran Mendikbud No. 4 Tahun 2020 tetang Pelaksanaan Kebijakan Pendidikan dalam Masa Darurat Penyebaran Covid-19., (2020).

Purwanto, A. (2020). Studi Eksplorasi Dampak Work From Home (WFH) Terhadap Kinerja Guru Selama Pandemi Covid-19. EduPsyCouns: Journal of Education, Psychology and Counseling, 2(1), 92-100.

Rohayani, F. (2020). Menjawab Problematika yang Dihadapi Anak 
Usia Dini di Masa Pandemi Covid19. Qawwam, 14(1), 29-50.

Sari, D. A., Mutmainah, R. N., Yulianingsih, I., Tarihoran, T. A., \& Bahfen, M. (2020). Kesiapan Ibu Bermain Bersama Anak Selama Pandemi Covid-19,"Dirumah Saja." Jurnal Obsesi: Jurnal Pendidikan Anak Usia Dini, 5(1), 475-489.

Syah, R. H. (2020). Dampak Covid-19 pada Pendidikan di Indonesia: Sekolah, Keterampilan, dan Proses Pembelajaran. SALAM: Jurnal Sosial Dan Budaya Syar-I, 7(5), 395-402. https://doi.org/10.15408/sjsbs.v7i5.15 314

Widyanuratikah, I. (2020). Kemendikbud: Jangan Ada Tugas ke Anak PAUD Selama Pandemi. Retrieved from Republika website: https://republika.co.id/berita/q82y7w 428/kemendikbud-jangan-ada-tugaske-anak-paud-selama-pandemi

Yulisetyaningrum, $\quad$ Y. (2019). Perkembangan Sosial Emosional Anak Usia Pra Sekolah. Jurnal Ilmu Keperawatan Dan Kebidanan, 10(1), 221-228.

Yus, A. (2011). Model Pendidikan Anak Usia Dini. Jakarta: PrenadaMedia. 